\title{
One Cut Domain Family Member 2
}

National Cancer Institute

\section{Source}

National Cancer Institute. One Cut Domain Family Member 2. NCI Thesaurus. Code C157290.

One cut domain family member $2(504 \mathrm{aa}, \sim 54 \mathrm{kDa})$ is encoded by the human ONECUT2 gene. This protein is involved in transcriptional regulation and liver development. 